\title{
Alachlor - ecotoxicity of ozonation by-products
}

\author{
Ol'ga Čižmárová, Ronald Zakhar, Ján Derco \\ Department of Environmental Engineering, Faculty of Chemical and Food Technology, \\ Slovak University of Technology, Radlinského 9, 81237 Bratislava, Slovak Republic \\ oli.cizmarova@gmail.com
}

\begin{abstract}
This work focuses on the assessment of alachlor toxicity, its impact on aquatic and terrestrial ecosystems, non-target organisms, and humans, as well as with pesticide legislation in the European Union and Slovakia. In the experimental part, the pesticide alachlor was degraded by various ozone-based processes. Toxicity of the original substance and its degradation products was evaluated by ecotoxicity tests on white mustard and bulb onion. Respirometric measurements were performed to assess their effect on the microorganisms of activated sludge process. From the results it is possible to evaluate that the degradation of alachlor by ozonation at alkaline $\mathrm{pH}$ resulted in less toxic substances compared to the original pesticide.
\end{abstract}

Keywords: alachlor, ecotoxicity, ozonation, pesticides

\section{Introduction}

The use of pesticides has steadily increased annually since the mid-1950s and the total amount of active components used in pesticides is now around 2.5 million kilograms per year. Pesticides, as well as fertilizers, play an important role in agriculture and contribute to increasing global food production. However, they also have a significant negative impact on the environment causing serious damage to aquatic ecosystems. More than $98 \%$ of applied insecticides and $95 \%$ of herbicides do not reach the target pest but pass on and damage the environment, aquatic ecosystems, air, soil, and non-target organisms, including pollinators, beneficial birds, soil organisms etc. Although pesticide residue limits in food and water have been set by the EU, many important facts such as long-term impact and combination effect of several chemicals and stressors that are common in today's food and everyday life are not yet considered (Sousa et al., 2018).

Alachlor (2-chloro-N-(2,6-diethylphenyl)-N-(methoxymethyl) acetamide), which is one of the chloroacetanilide herbicides, is used to control grasses and weeds growth in corn, peanuts, soybeans, and other crops. Alachlor was one of the most used herbicides in the United States with more than 22,000 tonnes of this pesticide used in 1990. Herbicidal effects of alachlor are manifested by two mechanisms: it limits the plant's ability to produce growth proteins and it disrupts the increase in root length (Xu et al., 2001).

Alachlor belongs to the List of Dangerous Substances Relevant to the Slovak Republic, which was prepared within the Program of Reduction of Water Pollution by Harmful and Particularly Harmful Substances, to observed substances listed in Directive $2015 / 495 / \mathrm{EU}$ and priority substances listed in Directive 2013/39/EU. In 2017, monitoring of 21 selected pesticides and their metabolites in a representative sample of more than 170 water supplies in all regions of the Czech Republic was carried out. The limit values were exceeded in 18 (spring) and 13 (autumn) water sources, while the limit concentration of alachlor $\left(1 \mu \mathrm{g} \cdot \mathrm{L}^{-1}\right)$ was exceeded several times in most samples (Kotal et al., 2017). In 2002, $80,297 \mathrm{~kg}$ of alachlor was used in the Slovak Republic.

Alachlor is a potential human carcinogen. Although its exact effects have not been described, its effect as a carcinogen in animals has been confirmed. Numerous studies with laboratory animals have shown gastric, nasal, and thyroid tumours appearing after alachlor consumption. Direct contact with alachlor in humans has manifested by an allergic skin reaction that has grown into skin sensitization (Environmental and Occupational Health, 2003). In addition, human exposure to alachlor causes symptoms such as headaches, memory loss, and stuttering (Bloomfield, 2017). However, research on the effects of alachlor on human health is very limited. Lee et al. (2004) monitored the incidence of cancer among subjects who had manipulated alachlor for a long time and identified a possible association between alachlor application and the incidence of lymphatematopoietic cancer. Alachlor is also demonstrably toxic to fish and can leave long-term changes in aquatic ecosystems; in addition, it accumulates in vegetative parts of plants (Tsaboula et al., 2016; Mendes et al., 2017). Kim et al. (2020) studied the toxicity of alachlor on the marine ecosystem where exposure to alachlor $\left(\mathrm{EC}_{50}=0.373 \mathrm{mg} \cdot \mathrm{l}^{-1}\right)$ led to considerable decrease in marine dinoflagellate Prorocentrum minimum cell number and pigment content. Their findings 
suggest that alachlor affects the microalgae photosystem function causing severe physiological damage to the cells, even leading to apoptosis.

Ozone reacts with inorganic and organic components by two mechanisms: direct ozonation with molecular ozone, or indirectly by producing radical intermediates. Hydroxyl radical $\left(\mathrm{HO}^{*}\right)$ has a higher redox potential $(2.8 \mathrm{~V})$ than ozone $(2.07 \mathrm{~V})$ and reacts non-selectively with pollution at high reaction rates. In addition to the hydroxyl radical, other reactive oxygen intermediates are produced: superoxide radical anions $\left(\mathrm{O}_{2}{ }^{\cdot-}\right)$, hydroperoxyl radicals $\left(\mathrm{HOO}{ }^{*}\right)$ and organic peroxyl radicals $\left(\mathrm{ROO}^{\circ}\right)$, which are also involved in indirect reactions in ozonation and ozone-based AOPs (Beltrán, 2003).

The purpose of toxicity tests is to identify or estimate the potential toxic effects of a test substance on living organisms. Ecotoxicological tests are nonspecific, meaning that they capture the overall toxic effects of all substances present in the test samples without further information on their composition or chemical structure.

The production and use of alachlor have been banned in the European Union, but this pesticide is still detected in aquatic ecosystems across Europe due to its persistence, adsorption to soil particles and low water solubility.

For these reasons, it is necessary to look for advanced processes for its degradation leading to less toxic intermediates. Advanced oxidation processes using ozone are often studied and efficient processes used in the degradation of micropollutants. In this work, degradation and detoxication of ala- chlor by ozone-based processes, such as ozonation at pH 10 and 7 and combined process of ozonation with UV was studied. The chlorides concentration was the monitored parameter in these processes. An increase in concentration indicated efficient dehalogenation of pesticides. Also, the presence of halogens in the molecule increases their toxic effect in aquatic ecosystems, and thus their successful removal indicates the production of less toxic intermediates as observed by ecotoxicity tests on Sinapis alba and Allium cepa. Conventional wastewater treatment plants processes may be adversely affected in the presence of micropollutants when biological wastewater treatment is used. Therefore, in the next part of the work, inhibitory effect of alachlor and its oxidation by-product from the $\mathrm{O}_{3} / \mathrm{pH}=10$ process on the activity of activated sludge are compared.

\section{Material and Methods}

\section{Ozone-based processes}

The process of ozonation $\left(\mathrm{O}_{3}\right)$, ozonation at elevated $\mathrm{pH}\left(\mathrm{O}_{3} / \mathrm{pH}=10\right)$, and combined ozonation $\left(\mathrm{O}_{3} / \mathrm{UV}\right)$ were performed in an ozonation reactor with external recirculation of the reaction mixture (Fig. 1) with the volume of $3.5 \mathrm{l}$ and height of $1 \mathrm{~m}$, recirculation rate was $150 \mathrm{l} \cdot \mathrm{h}^{-1}$. Ozone generator LifeTech with maximum ozone production of $5 \mathrm{~g} \cdot \mathrm{h}^{-1}$ was set at $50 \%$ of the maximum output. Oxygen flow for ozone production was $40 \mathrm{l} \cdot \mathrm{h}^{-1}$, laboratory temperature was $20^{\circ} \mathrm{C}$ and the reaction time was $180 \mathrm{~min}$. The monitored parameters indicating the ozonation

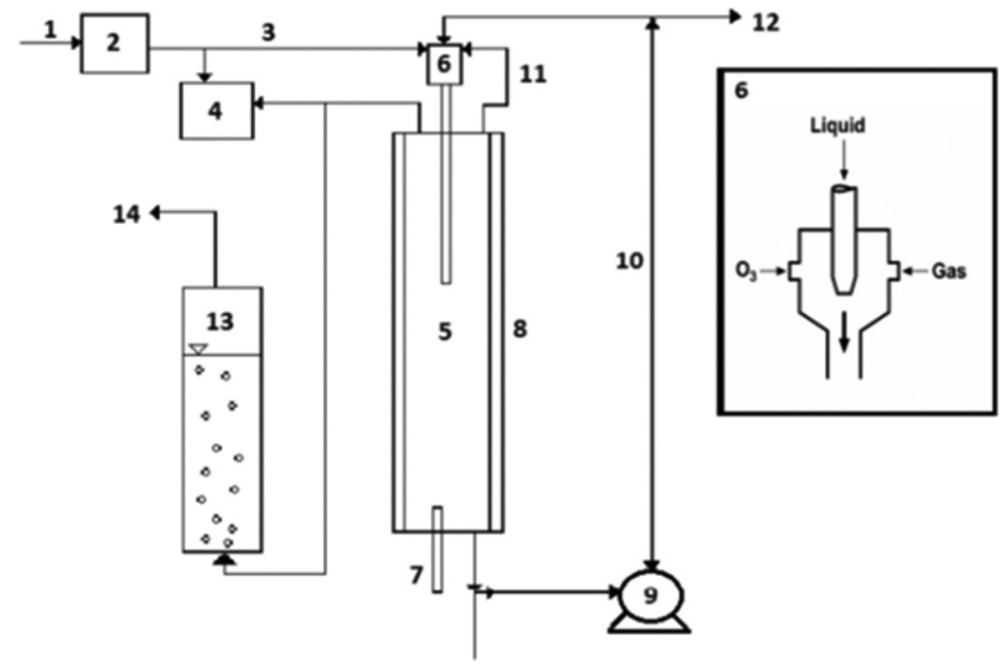

Fig. 1. Scheme of ozonation reactor with external recirculation of reaction mixture. 1 - oxygen supply, 2 - ozone generator, 3 - mixture of oxygen and ozone, 4 - detector of ozone concentration in the gas phase, 5 - ozonation reactor, 6 - Venturi ejector (detailed view on the right side), 7 - UV lamp,

8 - tempering jacket, 9 - pump, 10 - external recirculation of the reaction mixture,

11 - recirculation of gas from the reactor head, 12 - sampling, 13 - column for destruction of unreacted ozone filled with KI solution, 14 - gas mixture outlet. 
process efficiency were the concentration of chlorides and the efficiency of ozone utilization in the reactor. Chloride concentration was determined by argentometric titration.

Initial concentration of alachlor $\left(c_{0}\right)$ was $0.1 \mathrm{mmol} \cdot \mathrm{l}^{-1}$ and test solutions were prepared by dissolving the pesticide in deionized water. Concentration of chlorides in the alachlor test sample was determined by argentometric titration according to Horáková et al. (2003). Chloride concentration was used as indirect parameter determining the level of alachlor molecule fragmentation in the ozonation process.

\section{Ozone transfer}

During the ozone-based experiments, ozone transfer efficiency was monitored; specifically the transfer of ozone from the gas mixture into the liquid phase. The rate of ozone transfer can be expressed by equation (1),

$$
\frac{\mathrm{d} c}{\mathrm{~d} t}=K_{L} a \times\left(C_{S}-C\right)
$$

where, $K_{L} a$ - volumetric ozone transfer coefficient $\left(\mathrm{s}^{-1}\right), C_{S}$ - saturation concentration of ozone $\left(\mathrm{mg} \cdot \mathrm{l}^{-1}\right)$, $C$ - concentration of dissolved ozone $\left(\mathrm{mg} \cdot \mathrm{l}^{-1}\right)$.

\section{Toxicity tests}

Sub-acute toxicity tests on white mustard (Sinapis alba) were performed according to the method described in OECD Guidelines 208: "Terrestrial plants, Growth tests" (OECD 208, 2003). The tests were performed in three parallels in Petri dishes with a diameter of $10 \mathrm{~cm}$. The test samples were prepared in volume of $5 \mathrm{ml}$ from 1:1 solution of diluting water and alachlor solution in a Petri dish, $\mathrm{pH}$ was adjusted to 7. Subsequently, 30 white mustard seeds were placed on filtration paper. After 72-hour cultivation in dark, the length of the roots of each plant were measured.

Toxicity test on white onion (Allium cepa) was carried out in six parallels in test tubes. Bulbs with sprouted roots were immersed in the test solution to germinate for seven days in a bright place at room temperature. At the end of the experiment, the length of the roots to the nearest $1 \mathrm{~mm}$ and the loss of biomass dried at $105^{\circ} \mathrm{C}$ were measured.

\section{Respirometric measurements}

Respirometric measurements were carried out in a $300 \mathrm{ml}$ oxygen bank filled with activated sludge $\left(X c=1 \mathrm{~g} \cdot \mathrm{L}^{-1} ; \theta_{X}=10 \mathrm{~d}\right)$, stirred and aerated. When the oxygen concentration increased to approximately $8 \mathrm{mg} \cdot \mathrm{L}^{-1}$, an oxygen probe was inserted into the bank and the decrease in oxygen concentration was monitored using an oximeter (Multi 3510 IDS -
WTW) for approximately $5 \mathrm{~min}$ (endogenous phase). Then, alachlor solution was injected into the system and the decrease in oxygen concentration was observed for another 30 min (exogenous phase). Inhibition of activated sludge microorganisms was evaluated using equation (2),

$$
\text { MO inhibition }=1-\frac{r_{X, \mathrm{ox}, \mathrm{tot}}}{r_{X, \mathrm{ox}, \mathrm{en}}} \times 100 \%
$$

where $r_{X, \text { ox tot }}\left(\mathrm{mg}_{\mathrm{O}_{2}} \cdot \mathrm{g}^{-1} \cdot \mathrm{h}^{-1}\right)$ - total respiration rate, $r_{X, \text { ox en }}\left(\mathrm{mg}_{\mathrm{O}_{2}} \cdot \mathrm{g}^{-1} \cdot \mathrm{h}^{-1}\right)-$ endogenous respiration rate.

\section{Mathematical and statistical treatment of experimental data}

Experimental data were processed using the dichlorination equation (3), which is similar to the equation of $\mathrm{BOD}_{5}$ (biochemical oxygen demand) or the oxygen transfer from air to water. For a batch reaction system, assuming a constant reaction volume, the following equation was derived:

$$
c_{t}=c_{\max }-\left(c_{\max }-c_{0}\right) \times \mathrm{e}^{\left(-R_{D} \times t\right)}
$$

where: $c_{t}\left(\mathrm{~g} \cdot \mathrm{m}^{-3}\right)-$ concentration of chlorides at time $t, c_{0}\left(\mathrm{~g} \cdot \mathrm{m}^{-3}\right)-$ concentration of chlorides at time $0, c_{\max }\left(\mathrm{g} \cdot \mathrm{m}^{-3}\right)-$ maximum concentration of chlorides, and $R_{D}\left(\mathrm{~min}^{-1}\right)-$ dehalogenation rate constant.

Statistic evaluation of experimental and calculated data fit was determined by parameters $R_{y x}, S_{R}^{2}$ and $S_{y}^{2}$ according to equations (4-6),

$$
\begin{gathered}
S_{R}^{2}=\frac{\sum\left(y_{i}^{\text {exp. }}-y_{i}^{\text {calc. }}\right)^{2}}{n-m} \\
R_{y x}=1-\frac{(n-m) S_{R}^{2}}{(n-1) S_{y}^{2}} \\
S_{y}^{2}-\frac{n \sum y_{i}^{2}-\left(\sum y_{i}\right)^{2}}{n \times(n-1)}
\end{gathered}
$$

where $S_{R}^{2}$ - residual scatter $\left(\mathrm{mg}^{2} \cdot \mathrm{l}^{-2}\right), n-$ number of measurements, $m$ - number of parameters, $R_{y x}$ correlation coefficient, $S_{y}^{2}$ - variability $\left(\mathrm{mg}^{2} \cdot \mathrm{l}^{-2}\right)$.

\section{Results and discussion}

The obtained results show that the most effective process for alachlor degradation is the $\mathrm{O}_{3} / \mathrm{UV}$ system (Fig. 2 and 3), closely followed by ozonation at $\mathrm{pH}=10\left(\mathrm{O}_{3} / \mathrm{pH} 10\right)$, where the mechanism of alachlor degradation by indirect ozonation through the production of radical intermediates was assumed (Qiang et al., 2010). UV radiation (254 nm) enhances ozone molecules activation 
and thus the reaction rate; the produced radicals (such as hydroxyl radicals, $\mathrm{HO}^{\circ}$ ) attack organic pollutants (Hassanshahi and Karimi-Jashni, 2018). Dehalogenation of alachlor by both $\mathrm{O}_{3} / \mathrm{pH} 10$ and $\mathrm{O}_{3}$ /UV systems was described using the dichlorination equation (2) (Table 1). Dehalogenation rate of alachlor in the $\mathrm{O}_{3} / \mathrm{UV}$ process was $0.028 \mathrm{~min}^{-1}$ with good experimental data fit $\left(R_{y x}=0,994\right)$. In case of ozonation at neutral $\mathrm{pH}$, no decrease in the chloride concentration was observed during the reaction time of $180 \mathrm{~min}$. It is assumed that chlorides were not released from the alachlor molecule in this process, and the observed fluctuation in the chloride concentration was due to the limited solubility of alachlor in water. Similar results were obtained by Qiang et al. (2010), who investigated the degradation mechanism of alachlor during direct and indirect ozonation (represented by AOPs system $\mathrm{O}_{3} / \mathrm{H}_{2} \mathrm{O}_{2}$ ), identifying twelve different high-molecular by-products (with intact aromatic ring) from direct and eight by-products from indirect ozonation. Further, both systems led to the production

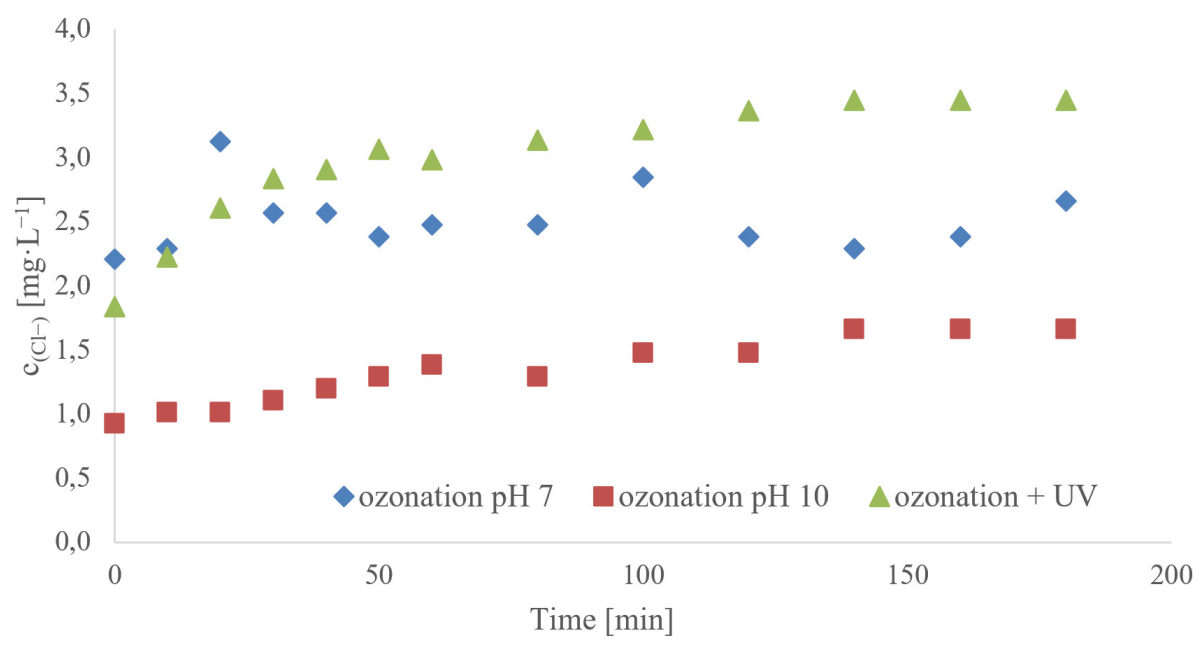

Fig. 2. Concentration of chlorides in alachlor mixture as a function of time in $\mathrm{O}_{3} / \mathrm{pH} 7, \mathrm{O}_{3} / \mathrm{pH} 10$ and $\mathrm{O}_{3} / \mathrm{UV}$ processes.

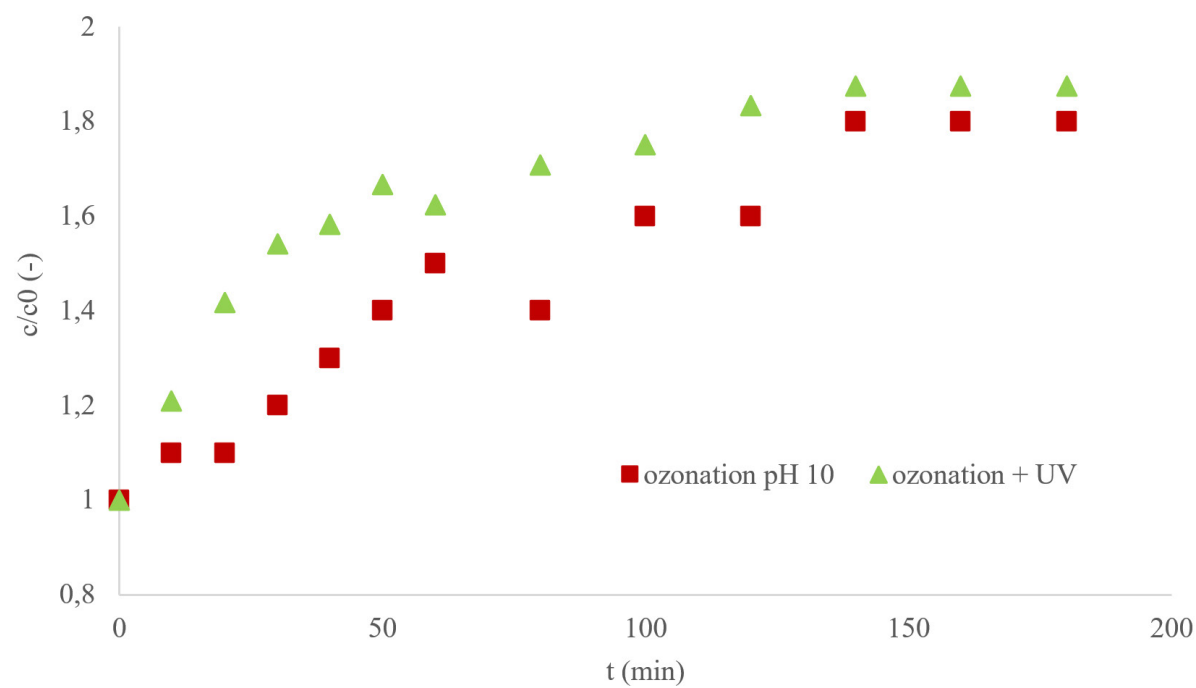

Fig. 3. Relative concentration of chlorides in alachlor mixture in time in $\mathrm{O}_{3} / \mathrm{pH} 10$ and $\mathrm{O}_{3} / \mathrm{UV}$ processes.

Tab. 1. Dehalogenation rate constants and statistic parameters for $\mathrm{O}_{3} / \mathrm{pH} 10$ and $\mathrm{O}_{3} / \mathrm{UV}$ processes when applied to alachlor degradation.

\begin{tabular}{lcccc}
\hline \multirow{2}{*}{ Process } & \multicolumn{3}{c}{ Parameters } \\
& $\boldsymbol{R}_{\boldsymbol{D}}\left(\mathrm{min}^{-1}\right)$ & $\boldsymbol{R}_{y x}(-)$ & $\boldsymbol{S}_{\boldsymbol{R}}^{2}\left(\mathrm{mg}^{2} \cdot \mathrm{l}^{-2}\right)$ & $\boldsymbol{S}_{y}^{2}\left(\mathrm{mg}^{2} \cdot \mathrm{l}^{-2}\right)$ \\
\hline O3/pH10 & 0.801 & 0.725 & 0.064 & 0.211 \\
O3/UV & 0.028 & 0.994 & 0.006 & 0.925 \\
\hline
\end{tabular}


of low molecular-weight by-products such as acetic, formic, and oxalic acids. In general, no dehalogenation was observed during direct ozonation, as the ozone molecule cannot easily remove bound chlorine, which is in agreement with our results. Chloride ions were detected only in the indirect ozonation system. The authors determined the degradation steps as follows: oxidation of arylethyl group, N-dealkylation and cyclization followed by cleavage of benzene ring. Radical reactions proceed faster than direct ozonolysis, but the main disadvantage is that, in addition to the target micropollutant, the oxidant is also consumed in the degradation of naturally present organic pollution, leading to the reduced process efficiency and increased economic costs (Ikehata and Li, 2018).

Efficiency of processes used for alachlor degradation was also evaluated in terms of effective use of supplied ozone (Fig. 4). The highest average efficiency of ozone utilization (64\%) was observed for the ozonation process $\left(\mathrm{O}_{3} / \mathrm{pH} 10\right)$, which is in agreement with the alachlor degradation efficiency of the process determined indirectly through chloride concentration. Efficiency of ozone utilization in the $\left(\mathrm{O}_{3} / \mathrm{pH} 7\right)$ process was only $15 \%$ and in the $\mathrm{O}_{3} / \mathrm{UV}$ process it was $38 \%$. Similar results on radical oxidation of alachlor were observed by Maldonado et al. (2006), who investigated partial degradation of a mixture of five pollutants (alachlor, atrazine, isoproturon, chlorfenvinpos and diuron) dissolved in distilled water with an addition of $35 \mathrm{~g} \cdot \mathrm{l}^{-1}$ of $\mathrm{NaCl}$ and real wastewater in a pilot ozonation reactor. Their finding can be summarized as follows: ozonation of a mixture of pesticides is a slow process, complete removal of TOC (total organic carbon) is difficult to achieve, chlorinated organic matter was not completely removed, and large amounts of ozone were wasted/unused due to poor ozone to liquid transfer. The observed low ozone utilization efficiencies can be also related to the low concentration $\left(0.1 \mathrm{mmol} \cdot \mathrm{L}^{-1}\right)$ of alachlor in model solution. Ecotoxicity of the herbicide alachlor and the obtained degradation products was evaluated by tests on white mustard and onion. The toxicity test on Allium cepa is based on the inhibition of root growth after seven days of exposure of the bulbs to the test substance in comparison with the control (in the absence of the toxicant). Souissi et al. (2013) investigated ecotoxicity of alachlor degradation products from UV degradation showing that alachlor intermediates after UV degradation have the same or even higher toxicity on the tested organisms - algae Pseudokirchneriella subcapitata, crustacean Daphnia magna and bacteria Vibrio fischeri. However, $\mathrm{O}_{3} / \mathrm{pH} 10$ and $\mathrm{O}_{3} / \mathrm{UV}$ systems were effective in producing less toxic intermediates. The results obtained (Fig. 5) indicate that the toxicity of degradation products from the $\mathrm{O}_{3} / \mathrm{pH} 10$ process (root growth inhibition of $24 \%$; biomass loss of $54 \%)$ is lower than that of the parent compound (root growth inhibition of $77 \%$; biomass loss of $69 \%$ ).

Pereira et al. (2021) studied and evaluated ecotoxicty of alachlor in multi model toxicity determination with in vitro bacterial, plant and animal model systems. Results of their work suggest that alachlor inhibits the growth of bacteria Bacillus stearothermophilus, proliferation of water plant Lemna gibba

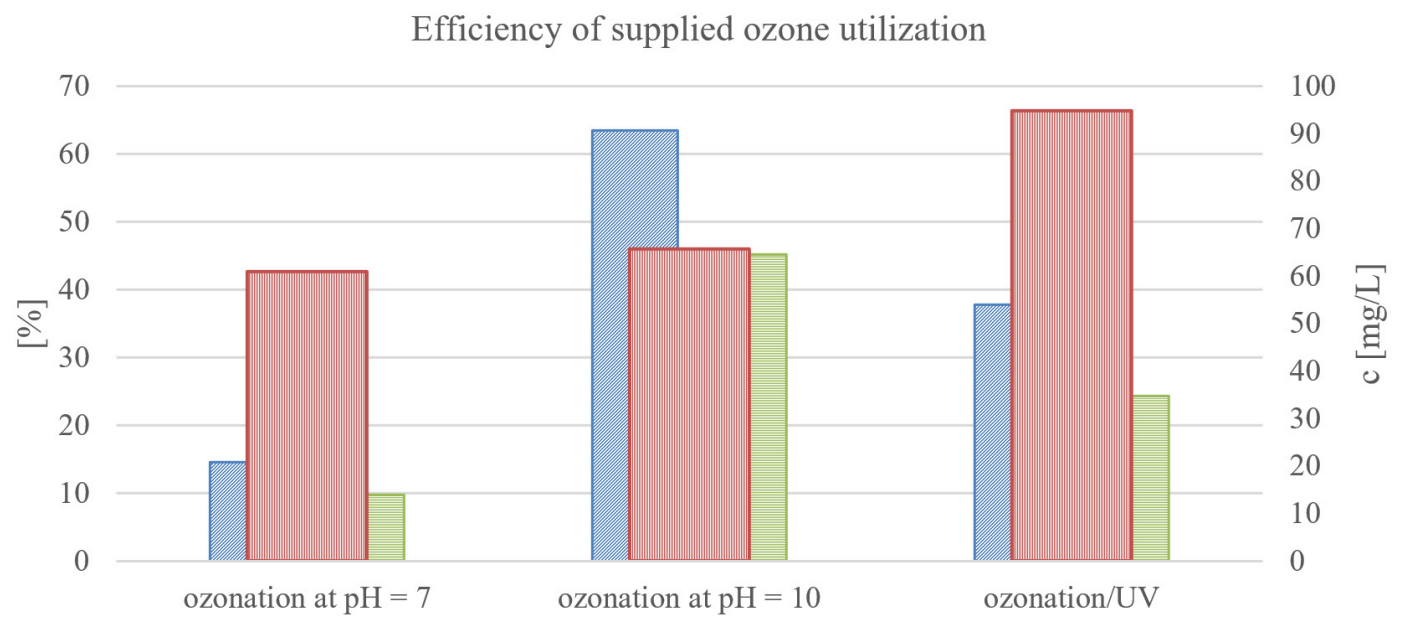

国 Average utilization efficiency of the supplied ozone (\%)

目Utilization efficiency of the supplied ozone at the end of the experiment (\%)

四 Transferred, reacted and decomposed ozone $[\mathrm{mg} / \mathrm{L}]$

Fig. 4. Utilization efficiency of supplied ozone for alachlor degradation in $\mathrm{O}_{3} / \mathrm{pH} 7, \mathrm{O}_{3} / \mathrm{pH} 10$ and $\mathrm{O}_{3} / \mathrm{UV}$ systems. 


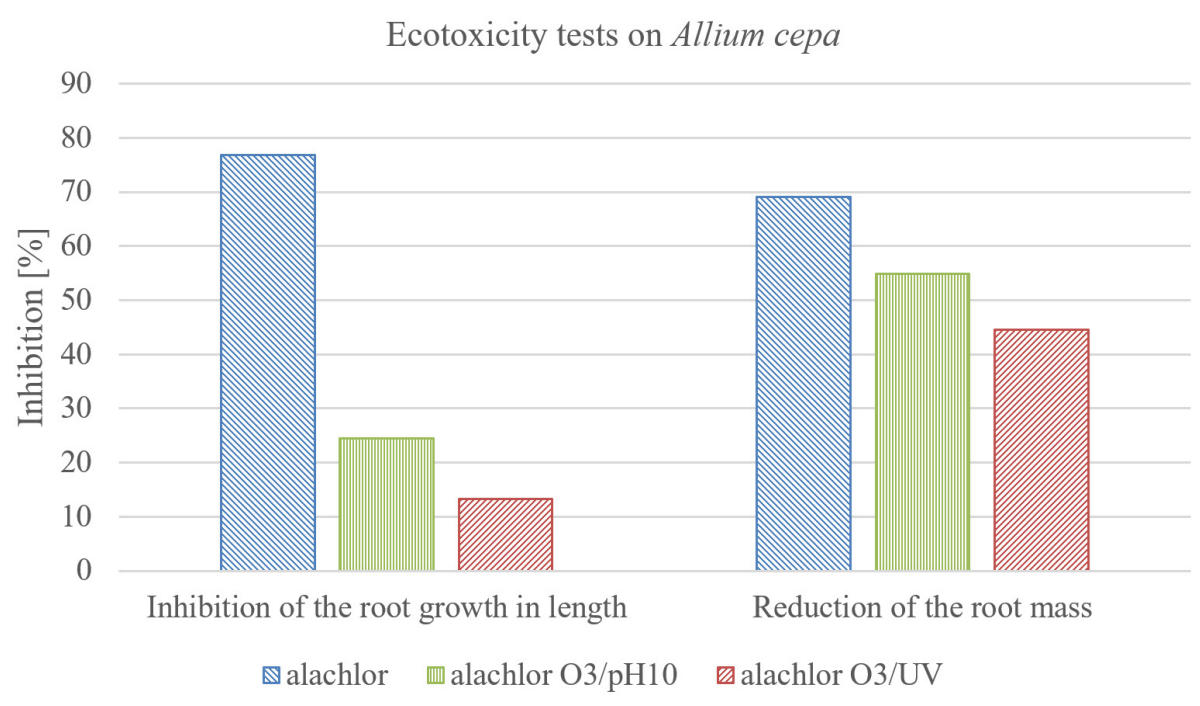

Fig. 5. Inhibition of onion root growth (\%) and biomass loss (\%), during toxicity test of alachlor solution $\left(0.1 \mathrm{mmol} \cdot \mathrm{L}^{-1}\right)$ and alachlor degradation products in $\mathrm{O}_{3} / \mathrm{pH} 10$ and $\mathrm{O}_{3} / \mathrm{UV}$ processes.

Inhibiton of Sinapis Alba roots growth

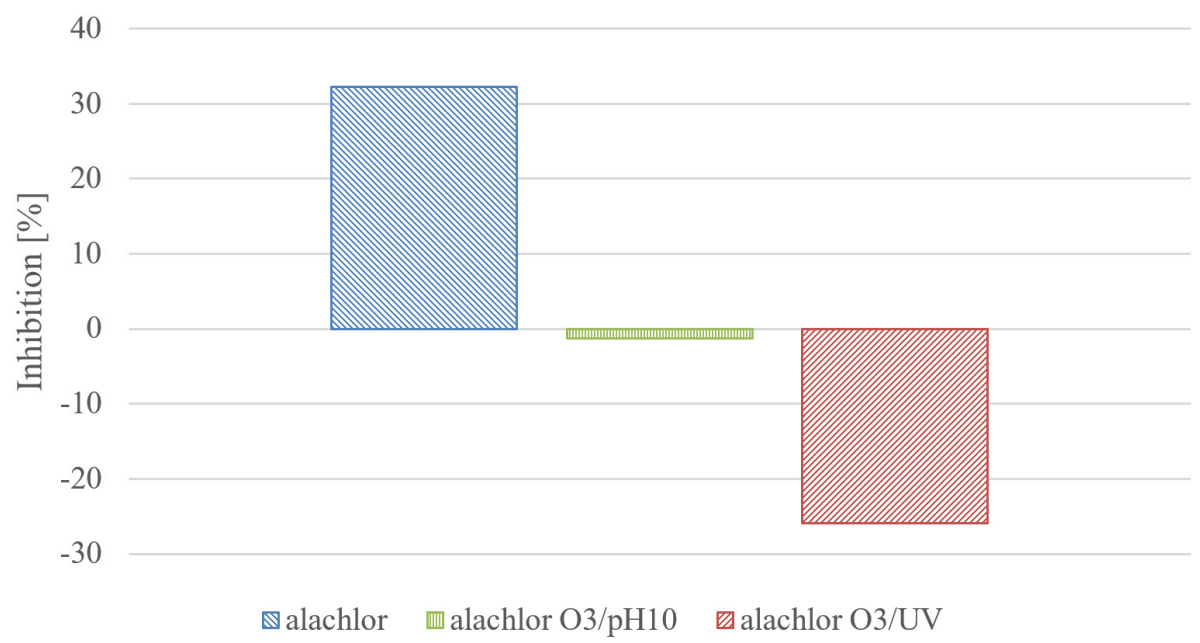

Fig. 6. Inhibition (or stimulation) of white mustard root growth (\%) during toxicity test of alachlor solution $\left(0.1 \mathrm{mmol} \cdot \mathrm{L}^{-1}\right)$ and alachlor degradation products of $\mathrm{O}_{3} / \mathrm{pH} 10$ and $\mathrm{O}_{3} / \mathrm{UV}$ processes.

and also reduces the viability of mammalian cells. These findings support the aims of this work to find degradation processes with less toxic by-products. The toxicity test on white mustard (Sinapis alba) is based on the inhibition of seed germination, and root growth after three days of mustard seeds exposure to the test substance compared to control (no toxicant present). The results obtained (Fig. 5) show that the parent pesticide alachlor has an inhibitory effect $(32 \%)$ on seed germination and root growth, and the degradation products of indirect alachlor ozonation have a stimulating effect on root growth and germination of white mustard seeds. Products of the $\mathrm{O}_{3} / \mathrm{pH} 10$ process show $6 \%$ stimulation and those of the $\mathrm{O}_{3} / \mathrm{UV}$ process show $17 \%$ stimulation of seed germination and white mustard root growth compared to the control.
Since organochlorinated pesticides are highly bioresistant, and some degradation processes (such as UV degradation) can lead to the formation of even more toxic by-products (Souissi et al., 2013), it is important to implement novel processes for ecotoxicity reduction. Results suggest that ozone-based processes $\mathrm{O}_{3} / \mathrm{pH} 10$ and $\mathrm{O}_{3} / \mathrm{UV}$, prioritizing the indirect ozonation pathway, lead to the formation of by-products with lower toxicity compared to the original herbicide.

Respirometric measurements with microorganisms (MO) of activated sludge were performed to assess the effect of alachlor on the activation process. Tab. 2 summarizes the parameters calculated from the obtained respirograms, where $V$ is the injection volume; $S$ substrate concentration; $r_{V, \text { ox }}$, volumetric endogenous respiratory rate; $r_{X, \mathrm{ox}}$, specific en- 
Tab. 2. Data obtained from respirometric measurements with activated sludge and exogenous substrates alachlor $\left(0.1 \mathrm{mmol} \cdot \mathrm{L}^{-1}\right)$ and alachlor degradation products of $\mathrm{O}_{3} / \mathrm{pH} 10$ system.

\begin{tabular}{|c|c|c|c|c|c|c|c|}
\hline $\begin{array}{l}\text { Test } \\
\text { substance }\end{array}$ & $\begin{array}{c}\boldsymbol{V}_{\text {substrate }} \\
{[\mathrm{mL}]}\end{array}$ & $\begin{array}{c}S \\
{\left[\mathrm{mg}_{\mathrm{COD}} \cdot \mathrm{L}^{-1}\right]}\end{array}$ & $\begin{array}{c}\boldsymbol{r}_{V, \mathbf{o x}, \mathbf{e n}} \\
{\left[\mathrm{mg}_{\mathrm{O}_{2}} \cdot \mathrm{L}^{-1} \cdot \mathrm{h}^{-1}\right]}\end{array}$ & $\begin{array}{c}\boldsymbol{r}_{X, \mathbf{o x}, \mathbf{e n}} \\
{\left[\mathrm{mg}_{\mathrm{O}_{2}} \cdot \mathrm{g}^{-1} \cdot \mathrm{h}^{-1}\right]}\end{array}$ & $\frac{r_{X, \mathbf{o x}, \mathbf{t}}}{\left[\mathrm{mg}_{\mathrm{O}_{2}} \cdot \mathrm{g}^{-1} \cdot \mathrm{h}^{-1}\right]}$ & $\begin{array}{c}\boldsymbol{r}_{X, \mathbf{o x}} \\
{\left[\mathrm{mg}_{\mathrm{O}_{2}} \cdot \mathrm{g}^{-1} \cdot \mathrm{h}^{-1}\right]}\end{array}$ & $\begin{array}{c}\text { MO } \\
\text { inhibition } \\
{[\%]}\end{array}$ \\
\hline alachlor & 20 & 2.12 & 7.24 & 5.88 & 5.30 & -0.58 & 9.89 \\
\hline $\begin{array}{l}\text { alachlor } \\
\mathrm{O}_{3} / \mathrm{pH} 10\end{array}$ & 20 & 2.94 & 9.96 & 8.74 & 6.70 & -2.04 & 23.33 \\
\hline
\end{tabular}

dogenous respiratory rate; $r_{X, \text { ox tot }}$ total respiration rate; $r_{X, 0 x}$ exogenous respiratory rate and $\mathrm{MO}$ inhibition (\%) calculated according to equation (4). The results (Tab. 2) show that the degradation of alachlor by the $\mathrm{O}_{3} / \mathrm{pH} 10$ system led to the production of substances with stronger inhibitory effect on the MO of activated sludge $(23 \%)$ than the original pesticide $(10 \%)$.

\section{Conclusion}

In this work, toxicity of the herbicide alachlor and its oxidation products was studied. Degradation of alachlor was performed by means of ozonation at $\mathrm{pH}$ of 7 and 10 and by the combined ozonation process with UV radiation. The toxicity of alachlor and its by-oxidation products was evaluated by tests on white mustard seeds and onion bulbs. Also, their effect on the metabolic activity of microorganisms of activated sludge was evaluated by respirometric measurements. The obtained results show that the products of oxidative degradation of alachlor by the $\mathrm{O}_{3} / \mathrm{pH} 10$ and $\mathrm{O}_{3} / \mathrm{UV}$ systems have lower inhibitory effect on the root growth of lower terrestrial plants, but they inhibit the MO of activated sludge to a greater extent than alachlor.

\section{References}

Beltrán FJ (2003) Ozone Reactions Kinetics for Water and Waste water Systems. Lewis Publishers, Boca Raton, FL. ISBN 978-15-66706-29-2.

Bloomfield F (2017) Alachlor-toxicity, side effects, diseases and environmental impacts. Available:

https://www.naturalpedia.com/alachlor-toxicity-sideeffects-diseases-and-environmental-impacts.html (visited 23. 1. 2021).
Environmental and occupational health (2003) Harmful Effect of Alachlor. Available: http://enhs.umn.edu/ current/5103/pesticide/harmful.html (visited 20. 3. 2020).

Hassanshahi N, Karimi-Jashni A (2018) Ecotoxicology \& Environ. Safety 161: 683-690.

Horáková M (2003) Water Analytics. Praha: VŠCHT pp. 187-188. ISBN 978-80-7080-520-6. In Slovak language.

Ikehata K, Li Y (2018) Advanced Oxidation Processes for Waste Water Treatment. Published by Elsevier Inc.: $115-134$.

Kim H, Wang H, Abassi S et al. (2020) J. Environ. Sci. \& Health B: 1-10.

Kotal F, Vavrouš A, Moulisová A et al. (2017) Proceeding of $7^{\text {th }}$ conference HYDROANALYTIKA (Hradec Králové, 12.-13. 9. 2017). CSlab s.r.o., Praha 2017: 69-76.

Lee WJ, Hoppin JA, Blair A et al. (2004) Am. J. Epidemiology 159(4): 373-380.

Maldonado MI, Malato S, Pérez-Estrada LA et al. (2006) J. Haz. Mat. 138: 363-369.

Mendes K, Hall K, Spokas K et al. (2017) Agronomy 7(4): 64.

Pereira SP, Santos SMA, Fernandes MAS et al. (2021) Environ. Pollution 286: 117239.

Qiang Z, Liu C, Dong B, Zhang Y (2010) Chemosphere 78: 517-526.

Souissi Y, Bouchonnet S, Bourcier S et al. (2013) Sci. Tot. Environ. 458: 527-534.

Sousa JCG, Ribeiro AR, Barbosa MO et al. (2018) J. Haz. Mat. 344: 146-162.

Tsaboula A, Papadakis EN, Vryzas Z et al. (2016) Environ. Int. 91: 78-93.

Xu J, Stucki JW, Wu J et al. (2001) Envi. Tox. \& Chem. 20: 2717-2724. 